\title{
Activation of the MAPK pathway is a common event in uveal melanomas although it rarely occurs through mutation of
} BRAF or RAS

\section{W Zuidervaart', F van Nieuwpoort ${ }^{2}$, M Stark ${ }^{3}$, R Dijkman², L Packer ${ }^{3}$, A-M Borgstein ${ }^{2}$, S Pavey ${ }^{3}$, $P$ van der Velden ${ }^{2}, C$ Out $^{2}$, MJ Jager', NK Hayward ${ }^{3}$ and NA Gruis ${ }^{*}, 2$}

'Department of Ophthalmology, Leiden University Medical Centre, PO Box 9600, 2300 RC, Leiden, The Netherlands; ' ${ }^{2}$ Department of Dermatology, Leiden University Medical Centre, Wassenaarseweg 72, 2333 AL, Leiden, The Netherlands; ${ }^{3}$ Queensland Institute of Medical Research, 300 Herston Rd, Herston, QLD 4029, Australia

In contrast to cutaneous melanoma, there is no evidence that BRAF mutations are involved in the activation of the mitogen-activated protein kinase (MAPK) pathway in uveal melanoma, although there is increasing evidence that this pathway is activated frequently in the latter tumours. In this study, we performed mutation analysis of the RAS and BRAF genes in a panel of I I uveal melanoma cell lines and 19 primary uveal melanoma tumours. In addition, Western blot and immunohistochemical analyses were performed on downstream members of the MAPK pathway in order to assess the contribution of each of these components. No mutations were found in any of the three RAS gene family members and only one cell line carried a BRAF mutation (V599E). Despite this, mitogenactivated protein kinase/extracellular signal-regulated kinase kinase (MEK), ERK and ELK were constitutively activated in all samples. These data suggest that activation of the MAPK pathway is commonly involved in the development of uveal melanoma, but occurs through a mechanism different to that of cutaneous melanoma.

British Journal of Cancer (2005) 92, 2032-2038. doi:I0.1038/sj.bjc.6602598 www.bjcancer.com (C) 2005 Cancer Research UK

Keywords: MAPK pathway; uveal melanoma; BRAF; RAS; mutation

\begin{abstract}
Uveal melanoma is the most common primary intraocular tumour in adults, with an annual incidence of 6-8 new cases per million among Caucasian populations. Up to half of all patients die from metastatic disease (Diener-West et al, 1992). In spite of several known prognostic markers (pathologic and genetic), such as tumour cell type, diameter, localisation and cytogenetic abnormalities, little is known about specific genes associated with predisposition and progression in uveal melanoma (Mooy and de Jong, 1996; Sisley et al, 1997). Notable exceptions are hypermethylation of $C D K N 2 A$, which is more common in tumours from patients who develop metastatic disease (van der Velden et al, 2001), and germline BRCA2 gene mutations, which occur in $3 \%$ of patients younger than 50 years of age (Scott et al, 2002). Hence, the search for other genes and molecular pathways involved in uveal melanoma development is of great significance. In contrast to uveal melanoma, the influence of specific pathways in cutaneous melanoma, which shares the same embryonic origin, is better defined. For instance, the tumour suppressor gene PTEN, encoding a dual-specific phosphatase and a member of the PI3AKT pathway, plays a major role in the pathogenesis of cutaneous melanoma (Guldberg et al, 1997; Stahl et al, 2003), whereas no mutations in this gene have been found in uveal melanoma (Naus et al, 2000).
\end{abstract}

*Correspondence: Dr NA Gruis, E-mail: gruis@lumc.nl

Received I December 2004; revised 10 March 2005; accepted 24 March 2005
Recently, the RAS-RAF-MEK-ERK or mitogen-activated protein kinase (MAPK) pathway has been found to play an important role in melanocytic neoplasia (Cohen et al, 2002; Satyamoorthy et al, 2003). Activation of this pathway in cutaneous melanocytes has been shown to occur by a variety of mechanisms, including autocrine growth factor stimulation and mutation of the RAS or $B R A F$ genes. Of three RAS genes found to be activated by mutation in human tumours, NRAS (neuroblastoma RAS viral (vras) oncogene homologue) is most commonly mutated in cutaneous melanomas (van Elsas et al, 1996). In the active GTPbound state, RAS activates a number of downstream signalling cascades involved in controlling cell growth and behaviour. Initially, RAS interacts with and activates the serine/threonine protein kinase BRAF that acts in the MAPK pathway to transduce regulatory signals from RAS to mitogen-activated protein kinase/ extracellular signal-related kinase kinase (MEK1/2). The signal transducer MEK1/2 phosphorylates extracellular signal-regulated kinase (ERK1/2, p44/42), leading to the activation of these kinases, which in turn activate a variety of transcription factors, including ELK1, again through phosphorylation. It has emerged that $B R A F$ (v-raf murine sarcoma viral oncogene homologue B1) is very frequently activated by mutation in cutaneous melanomas (Brose et al, 2002; Davies et al, 2002; Alsina et al, 2003; Dong et al, 2003; Gorden et al, 2003; Kumar et al, 2003a,b; Maldonado et al, 2003; Omholt et al, 2003; Pollock et al, 2003; Rimoldi et al, 2003; Satyamoorthy et al, 2003; Weber et al, 2003; Cohen et al, 2004; Reifenberger et al, 2004; Shinozaki et al, 2004; Tsao et al, 2004). The frequency of $B R A F$ mutations varies from 8 to $83 \%$ depending 
on the anatomic site of the lesion and its histogenic subtype. Notably, the frequency of $B R A F$ mutations is also high in benign melanocytic naevi (Dong et al, 2003; Pollock et al, 2003; Uribe et al, 2003; Yazdi et al, 2003), indicating that constitutive activation of the MAPK pathway is an early event in melanomagenesis. All BRAF mutations in cutaneous pigmented neoplasms occur within the kinase domain. The most frequently found mutation in BRAF (V599E) consists of a $1796 \mathrm{~T} \rightarrow \mathrm{A}$ transversion in exon 15 (Davies et al, 2002). Various other mutations have been described in this exon in melanocytic tumours (V599D (Brose et al, 2002; Davies et al, 2002; Pollock et al, 2003); V599K (Pollock et al, 2003, Uribe et al, 2003); V599R (Pollock et al, 2003); K600E (Brose et al, 2002, Satyamoorthy et al, 2003)). All other mutations have been described in exon 11. The latter consist of a $1352 \mathrm{~A} \rightarrow \mathrm{C}$ transversion (K438Q) (Brose et al, 2002), a 1402G $\rightarrow$ A transition $(\mathrm{G} 468 \mathrm{R})$ and a $1402 / 1403 \mathrm{GG} \rightarrow \mathrm{TC}$ tandem transversion (Gorden et al, 2003), a $1394 \mathrm{G} \rightarrow \mathrm{A}$ transition (G465E) and a $1394 \mathrm{G} \rightarrow \mathrm{C}$ transversion (G465A) (Davies et al, 2002). Furthermore, it is not surprising that since they activate the same pathway, mutations in NRAS and BRAF are almost mutually exclusive (Brose et al, 2002; Davies et al, 2002; Alsina et al, 2003; Dong et al, 2003; Gorden et al, 2003; Kumar et al, 2003a,b; Omholt et al, 2003; Pollock et al, 2003; Satyamoorthy et al, 2003; Reifenberger et al, 2004; Tsao et al, 2004).

Since cutaneous and uveal melanoma both arise from neural crest-derived melanocytes, we sought to assess whether the MAPK pathway was similarly activated in melanoma of the uvea. We thus screened for activating mutations in the NRAS, HRAS, $K R A S$ and BRAF genes in uveal melanoma cell lines and primary uveal melanomas. Sequence analysis was performed on exons 11-15 of BRAF, and exons 1 and 2 of the three RAS family members, which cover the positions of all known mutations of these genes in all types of cancer. In addition, we performed immunohistochemistry and Western blot analysis with MEK, ERK and ELK antibodies both on cell lines and/or primary tumours to assess the level of expression and degree of activation of these proteins in order to provide insight into the involvement of this pathway in the development of uveal melanoma.

\section{MATERIALS AND METHODS}

\section{Cell lines and primary uveal melanoma specimens}

In total, 11 uveal melanoma cell lines, derived from primary uveal melanomas (Mel202, Mel 285, Mel 270, Mel 290, Ocm 1, Ocm 3, 92.1, 92.2) or uveal melanoma metastases (Omm $1 \mathrm{Omm} 1.3$ and Omm 1.5), were analysed. Mel 202, Mel 285, Mel 270, Mel 290 and the two cell lines derived from metastases (Omm 1.3 and Omm 1.5) were kindly provided by Dr BR Ksander (Schepens Eye Institute, Boston, MA, USA). Omm 1, obtained from a subcutaneous metastasis, was established by Dr Luyten (Luyten et al, 1996). The cell lines Ocm 1 and Ocm 3 were provided by Dr Kan-Mitchell (Kan-Mitchell et al, 1989) and cell lines 92.1 and 92.2, derived from the same primary tumour were established in our own laboratory (de Waard-Siebinga et al, 1995). The melanoma cell lines were cultured in RPMI 1640 (Gibco, Paisley, Scotland) medium, supplemented with $3 \mathrm{~mm}$ L-glutamine (Gibco), 2\% penicillin/ streptomycin and 10\% FBS (Hyclone, Logan, UT, USA). All cell cultures were incubated at $37^{\circ} \mathrm{C}$ in a humidified $5 \% \mathrm{CO}_{2}$ atmosphere. In addition, we analysed 19 primary fresh frozen uveal melanomas. Of the primary tumours, eight were located in the choroid and 11 in both the choroid and ciliary body. Four of these samples showed a spindle cell type, one an epithelioid cell type and 14 had a mixed population of cells. All samples were derived from tumours with a diameter greater than $12 \mathrm{ml}$ and a prominence greater than $6 \mathrm{ml}$. The research protocol followed the tenets of the Declaration of Helsinki (World Medical Association Declaration of Helsinki 1964; ethical principles for medical research involving human subjects).

\section{Sequencing}

DNA was extracted from each cell line using an adaptation of the salting-out method (Miller et al, 1988). Primers used to amplify parts of the BRAF and RAS genes are given in Table 1.

Reactions for BRAF contained 200 ng of DNA, QIAGEN (Hilden, Germany) PCR buffer $(10 \times$ concentrated, containing Tris-Cl, $\mathrm{KCl}$, $\left(\mathrm{NH}_{4}\right)_{2} \mathrm{SO}_{4}, 15 \mathrm{mM} \mathrm{MgCl}$; $\left.\mathrm{pH} 8.7\right)$, Q solution (PCR enhancer),

Table I PCR primers for BRAF, NRAS, KRAS and HRAS genes

\begin{tabular}{|c|c|c|c|c|c|}
\hline Samples & Gene & Exon/region & Primer name & Primer sequence $\left(5^{\prime}>3^{\prime}\right)$ & Product size (bp) \\
\hline \multirow{16}{*}{$\begin{array}{l}\text { Cell lines } \\
\text { (DNA) }\end{array}$} & \multirow[t]{2}{*}{$B R A F$} & \multirow[t]{2}{*}{11} & $x|| F$ & СTCTCAGGCATAAGGTAATGTAC & \multirow{3}{*}{360} \\
\hline & & & $x|| R$ & GAGTCCCGACTGCTGTGAAC & \\
\hline & \multirow[t]{2}{*}{$B R A F$} & \multirow[t]{2}{*}{15} & $\times 15 F$ & CTAAGAGGAAAGATGAAGTACTATG & \\
\hline & & & $\times 15 R$ & CTAGTAACTCAGCAGCATCTCAG & \multirow[t]{2}{*}{328} \\
\hline & \multirow[t]{2}{*}{ NRAS } & \multirow[t]{2}{*}{1} & $X I F$ & CTGGTTTCCAACAGGTTCTTG & \\
\hline & & & $X \mid R$ & TGCTACTCCAATCATCTGGTC & \multirow[t]{2}{*}{567} \\
\hline & \multirow[t]{2}{*}{ NRAS } & \multirow[t]{2}{*}{2} & $\times 2 F$ & CACACCCCCAGGATTCTTAC & \\
\hline & & & $\times 2 R$ & GTTCCAAGTCATTCCCAGTAG & \multirow[t]{2}{*}{438} \\
\hline & \multirow[t]{2}{*}{ HRAS } & \multirow[t]{2}{*}{1} & $X \mid F$ & GGCAGGAGACCCTGTAGGA & \\
\hline & & & $X \mid R$ & AGCCCTATCCTGGCTGTGT & \multirow[t]{2}{*}{232} \\
\hline & \multirow[t]{2}{*}{ HRAS } & \multirow[t]{2}{*}{2} & $\mathrm{X} 2 \mathrm{~F}$ & AGAGGCTGGCTGTGTGAACT & \\
\hline & & & $\times 2 R$ & ACATGCGCAGAGAGAGGACAG & \multirow[t]{2}{*}{344} \\
\hline & \multirow[t]{2}{*}{ KRAS } & \multirow[t]{2}{*}{1} & $X \mid F$ & GATाTCCTAGGCGGCGG & \\
\hline & & & $X \mid R$ & GTCCGCTCCGTACCTCTCTC & \multirow[t]{2}{*}{199} \\
\hline & \multirow[t]{2}{*}{ KRAS } & \multirow[t]{2}{*}{2} & $\mathrm{X} 2 \mathrm{~F}$ & GGCCTGCTGAAAATGACTG & \\
\hline & & & $\times 2 R$ & TATTGTTGGATCATATTCGTCCAC & \multirow[t]{2}{*}{120} \\
\hline Tumours & \multirow[t]{2}{*}{$B R A F$} & \multirow[t]{8}{*}{$11-15$} & F & TCAACCACAGGTTTGTCTGC & \\
\hline (cDNA) & & & $\mathrm{R}$ & GATGACTTCTGGTGCCATCC & \multirow[t]{2}{*}{696} \\
\hline & \multirow[t]{2}{*}{ NRAS } & & $\mathrm{F}$ & GGGGTCTCCAACATTTTTCC & \\
\hline & & & $\mathrm{R}$ & TCGCTTAATCTGCTCССTGT & \multirow[t]{2}{*}{390} \\
\hline & \multirow[t]{2}{*}{ HRAS } & & $\mathrm{F}$ & CAGGAGACCCTGTAGGAGGA & \\
\hline & & & $\mathrm{R}$ & TTIACTGTGATCCCATCTGTGC & \multirow[t]{2}{*}{968} \\
\hline & \multirow[t]{2}{*}{ KRAS } & & $\mathrm{F}$ & AGGCCTGCTGAAAATGACTG & \\
\hline & & & $\mathrm{R}$ & TTCAATCTGTATTGTCGGATCTC & 519 \\
\hline
\end{tabular}


$20 \mathrm{pmol}^{-1} \mathrm{l}^{-1}$ of each primer, $2 \mathrm{~mm}$ of each dNTP and $1.25 \mathrm{U}$ of QIAGEN Taq polymerase. Amplification involved 35 cycles of denaturation at $94^{\circ} \mathrm{C}$ for $45 \mathrm{~s}$, annealing at $56^{\circ} \mathrm{C}$ for $90 \mathrm{~s}$, and extension at $72^{\circ} \mathrm{C}$ for $90 \mathrm{~s}$. An initial $12 \mathrm{~min}$ denaturation step at $94^{\circ} \mathrm{C}$ and a final $3 \mathrm{~min}$ extension at $72^{\circ} \mathrm{C}$ were also used. For the RAS genes, DNA was amplified using QIAGEN Taq polymerase as described above, but PCR involved a 'touchdown' thermal cycling routine of two cycles at each annealing temperature, decreasing by steps of $2{ }^{\circ} \mathrm{C}$, followed by 25 cycles at the lowest temperature. Each cycle consisted of denaturation at $94^{\circ} \mathrm{C}$ for $45 \mathrm{~s}$, annealing at $65-$ $57^{\circ} \mathrm{C}$ for $90 \mathrm{~s}$ and extension at $72^{\circ} \mathrm{C}$ for $90 \mathrm{~s}$. An initial $12 \mathrm{~min}$ denaturation at $94^{\circ} \mathrm{C}$ and a final 3 min extension at $72^{\circ} \mathrm{C}$ were also employed.

From 19 fresh frozen uveal melanoma samples, total RNA was extracted with RNeasy kits as described by the manufacturer (QIAGEN). RNA was primed with random primers and reverse transcribed into cDNA in a $20 \mu \mathrm{l}$ reaction volume containing $200 \mathrm{U}$ Superscript II (MMV) reverse transcriptase (Invitrogen, Inc., Breda, The Netherlands). PCR primers used for amplifying parts of the $B R A F$ and $R A S$ genes in the primary tumour samples are also listed in Table 1. A touchdown PCR procedure for BRAF was followed as described above and a fixed annealing temperature of $57^{\circ} \mathrm{C}$ with a total of 38 cycles was used for the RAS genes followed by a final elongation step of $10 \mathrm{~min}$.

PCR products of all samples were electrophoresed through $1.5 \%$ TAE/agarose gels stained with ethidium bromide, excised and purified using a QIAGEN QIAquick Gel Extraction Kit. The RAS and $B R A F$ PCR products were sequenced using Applied Biosystems (ABI) BigDye version 3 reagents according to the manufacturer's instructions using $3.2 \mathrm{pmol} \mu \mathrm{l}^{-1}$ of primer. Sequencing products were precipitated using $75 \%$ isopropanol and were run on an ABI 377 automated sequencer (PE Applied Biosystems, Foster City, CA, USA).

\section{Western blot analysis}

Protein lysates from the uveal melanoma cell lines were separated on $12.5 \%$ SDS - PAGE gels and the proteins transferred to Hybondpolyvinyldifluoride membranes (Amersham biosciences, Buckinghamshire, UK). After blocking with $5 \%$ skim milk in PBS-Tween solution, the membranes were probed overnight at $4{ }^{\circ} \mathrm{C}$ with the following primary antibodies specific to each antigen: phosphoMEK1/2 (dilution 1:1000), phospho-ERK1/2 (p44/42) (\#9106, dilution 1:5000), total ERK1/2 (\#9102, dilution $1: 1000)$ and phospho-ELK1 (dilution $1: 1000$ ) antibody (all from Cell Signaling Technology, Hertfordshire, UK). An antibody against actin (Santa Cruz Biotechnology, California, USA) was used as a loading control. Membranes were then incubated with horseradish peroxidaseconjugated IgG anti-mouse, anti-rabbit or anti-goat secondary antibodies for $1 \mathrm{~h}$ at room temperature to visualise protein bands.

\section{Immunohistochemistry}

Acetone-fixed $10 \mu \mathrm{m}$ sections of 19 fresh frozen uveal melanomas were washed three times in PBS $(\mathrm{pH}=7.2)$ and were incubated with anti-ERK1/2 and anti-phospho-ERK 1/2 antibodies (Cell Signalling Technology, Beverly MA, USA, \#9102 and \#9106, respectively), both diluted $1: 100$ in PBS with $1 \%$ BSA and $2 \%$ normal human serum (NHS) at $4^{\circ} \mathrm{C}$. The sections were washed three times and incubated with cy3-conjugated AffiniPure goat anti-rabbit IgG or with cy3-conjugated AffiniPure rabbit antimouse IgG (Jackson ImmunoResearch, West Grove PA, USA \#111165-003 and \#315-165-003) both diluted 1:500, respectively, during $1 \mathrm{~h}$ at room temperature. Sections were rinsed with PBS three times and incubated for $20 \mathrm{~min}$ with Alexa Fluor 647 Phalloidin (Molecular Probes, Leiden, The Netherlands, \#A22287) at a 1:40 dilution. Sections are washed three times with PBS. A nuclear staining was preformed by incubating the sections for
5 min with 4',6-diamidino-2-phenylindole dilacetate (DAPI, Molecular Probes, Leiden, The Netherlands, \#D-3571) 1:500. Sections were rinsed briefly in PBS and imbedded with Vectashield (Vecta Shield H1000, Brunschwig, Amsterdam, The Netherlands). For each specimen, the fluorescence of cy3 was determined in three different microscope fields (Leica DMRXA microscope, Leica Microsystems, Rijswijk, The Netherlands). No background fluorescence of cy3 was observed. The number of positively stained tumour cells was estimated for the two antibodies and expressed as the percentage of the total number of tumour cells in the analysed section. Percentages were then categorised as either negative $<5 \%$ $(+I-)$, very weakly positive $5-25 \%(+)$, weakly positive $26-50 \%$ $(++)$, moderately positive $51-75 \%(+++)$ or highly positive $76-100 \%(++++)$.

The slides were examined by two observers independently. Interobserver disagreement did not exceed one category.

\section{RESULTS}

\section{Mutation analysis}

Of the 11 uveal melanoma cell lines under study, only one cell line (Ocm 1) carried a BRAF mutation, the common V599E (also described by Calipel et al and Kilic et al). All primary tumour specimens were wild type for $B R A F$. No mutations were found in the NRAS, HRAS or KRAS genes, in both the cell lines and primary tissue.

\section{Western blotting}

In order to assess the level of expression and the activation (by phosphorylation) of members of the MAPK pathway downstream of $R A S$ and $B R A F$, Western blot analysis was performed on uveal melanoma cell lines (Table $2 \mathrm{~A}$ ). The expression levels of the downstream members of RAS and BRAF are presented in Figure 1. In response to the constitutively activating $B R A F$ mutation in $\mathrm{Ocm}$ 1 , downstream members of the MAPK pathway show activation (phosphorylated MEK, ERK and ELK). Levels of expression of the downstream members were not different in the two cell lines derived from the same primary tumour (92.1 and 92.2), except for phosphorylated MEK, indicating that there had been little clonal divergence between the cell populations during in vitro culturing. Interestingly, compared to the phosphorylation status of these members in Ocm 1, most cell lines show activation of MEK, ERK and ELK; however, these cell lines show this activation in the absence of mutations in the upstream RAS and BRAF genes. The levels of total ERK were remarkably similar across all cell lines, with the exception of two cell lines Mel 285 and Mel 290, which had significantly higher levels of total ERK than the others. In keeping with this observation, these two cell lines also have the highest levels of phosphorylated-ERK. Figure 2 shows that there is no significant influence of serum on the activity of ERK1/2 in these cell lines, as reported recently by Calipel et al (2003).

\section{Immunohistochemistry}

Immunofluorescence results of total and phospho-ERK1/2 on a panel of 19 fresh frozen uveal melanoma sections are listed in Table 2 (B). In seven of the 19 primary tumours, less than $5 \%$ of the tumour cells stained positively for ERK1/2 and nine tumours for phosphorylated ERK1/2. Despite the lack of mutations in the $R A S$ and BRAF genes in this set of uveal melanomas, it is noteworthy that we observed phosphorylated (active) ERK1/2 expression in 10 of 19 tumours. There was no significant association between ERK1/2 activation and tumour location or cell type. The scoring system for each antibody cannot be compared between antibodies since the antibodies recognise different epitopes and with different affinities; therefore, the 
Table 2 Summary of mutation analyses, immunohistochemical and Western blotting data in uveal melanoma cell lines and primary uveal melanomas (A) Uveal melanoma cell lines

\begin{tabular}{|c|c|c|c|c|c|c|c|c|}
\hline Cell line & $\begin{array}{c}\text { BRAF } \\
\text { mutation } \\
\text { analysis }\end{array}$ & $\begin{array}{c}\text { NRAS } \\
\text { mutation } \\
\text { analysis }\end{array}$ & $\begin{array}{c}\text { KRAS } \\
\text { mutation } \\
\text { analysis }\end{array}$ & $\begin{array}{c}\text { HRAS } \\
\text { mutation } \\
\text { analysis }\end{array}$ & $\begin{array}{l}\text { Total ERK } \\
\text { Western }\end{array}$ & $\begin{array}{c}\text { Phospho-ERK } \\
\text { Western }\end{array}$ & $\begin{array}{c}\text { Phospho-MEK } \\
\text { Western }\end{array}$ & $\begin{array}{c}\text { Phospho-ELK } \\
\text { Western }\end{array}$ \\
\hline \multicolumn{9}{|c|}{ From primaries } \\
\hline Ocm I & V599E & WT & WT & WT & +++ & +++ & ++++ & +++ \\
\hline Mel 285 & WT & WT & WT & WT & ++++ & ++++ & ++ & ++ \\
\hline Mel 290 & WT & WT & WT & WT & ++++ & ++++ & +++ & ++ \\
\hline 92.1 & WT & WT & WT & WT & +++ & ++ & +++ & +++ \\
\hline 92.2 & WT & WT & WT & WT & +++ & ++ & ++ & +++ \\
\hline Ocm 3 & WT & WT & WT & WT & +++ & ++ & ++++ & +++ \\
\hline Mel 202 & WT & WT & WT & WT & +++ & ++ & +++ & +++ \\
\hline Mel 270 & WT & WT & WT & WT & +++ & ++ & +++ & ++ \\
\hline \multicolumn{9}{|c|}{ From metastases } \\
\hline Omm 1.3 & WT & WT & WT & WT & +++ & + & + & +++ \\
\hline Omm 1.5 & WT & WT & WT & WT & +++ & + & + & +++ \\
\hline Omm I & WT & WT & WT & WT & +++ & + & ++++ & +++ \\
\hline
\end{tabular}

(B) Primary uveal melanomas

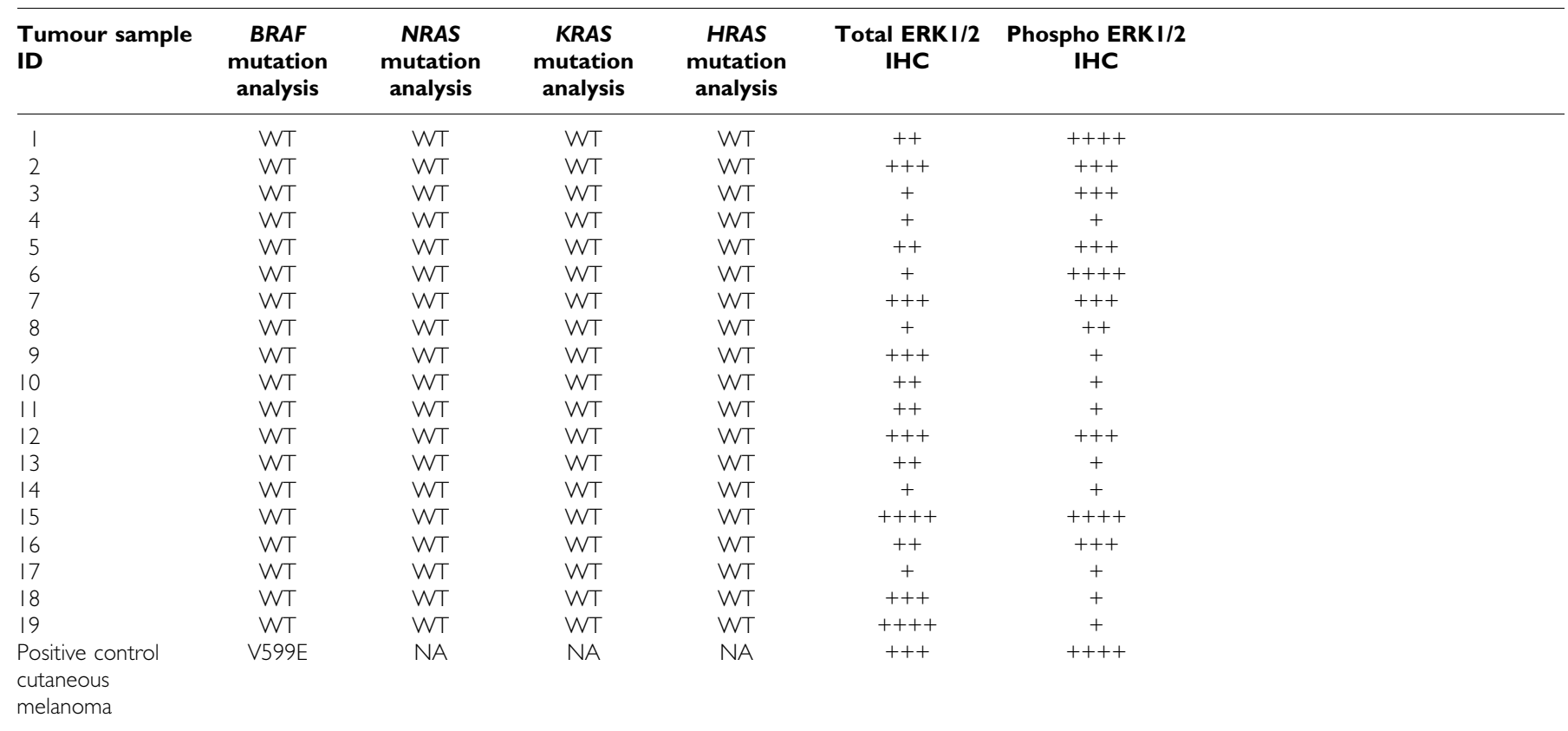

The level of expression of the Western blotting and immunhistochemistry $(\mathrm{IHC})$ experiments were scored and categorised as either negative $(-)$, weakly positive $(+)$, weakmoderately positive $(++)$, moderately positive $(+++)$ or strongly positive $(++++)$. NA $=$ not applicable.

staining intensity on Western or by immunohistochemistry is relative only to the other samples for the particular antibody used.

\section{DISCUSSION}

In the uveal melanoma cell lines and primary uveal melanomas analysed in our study, only cell line Ocm 1 carried a mutation in $B R A F$ (V599E), thus confirming the documentation of a mutation in this cell line by Calipel et al (2003) and Kilic et al (2004). Similarly, our observation of a complete lack of BRAF mutations in primary uveal tumours mirrors the findings of several recent reports (Cohen et al, 2003; Cruz et al, 2003; Edmunds et al, 2003; Rimoldi et al, 2003; Weber et al, 2003; Kilic et al, 2004). Table 3 contains a summary of published reports on RAS and BRAF mutations, as well as studies on other members of the MAPK pathway, in uveal melanomas. Including the results of our study, to date not a single BRAF mutation has been found in a total of 276 primary or secondary uveal melanoma samples (Table 3 ). It is somewhat surprising therefore that three out of three uveal melanoma cell lines studied by Calipel et al (2003) carried the V599E mutation in BRAF, especially since only one out of 11 cell lines in the panel we analysed was found to have this mutation. Taken together, these data suggest that while a BRAF mutation is not required for uveal melanoma development in vivo, such mutations confer a cellular growth advantage and are hence selected if they occur in cell lines cultured in vitro.

In our study, none of the cell lines or primary tumours carried mutations in any of the three $R A S$ genes $(\mathrm{N}, \mathrm{H}$ and $\mathrm{K})$, a finding consistent with a previous report (Soparker et al, 1993). These mutation data are in stark contrast to that for cutaneous melanoma, and would appear to suggest that the MAPK pathway is unlikely to play a significant role in uveal melanoma development. However, on the contrary, by Western blot analysis and immunohistochemistry, we have found substantial evidence for activation of the MAPK pathway, in the absence of serum, in the majority of uveal melanoma samples - both cell lines and primary uveal melanoma specimens. This frequent MAPK pathway 


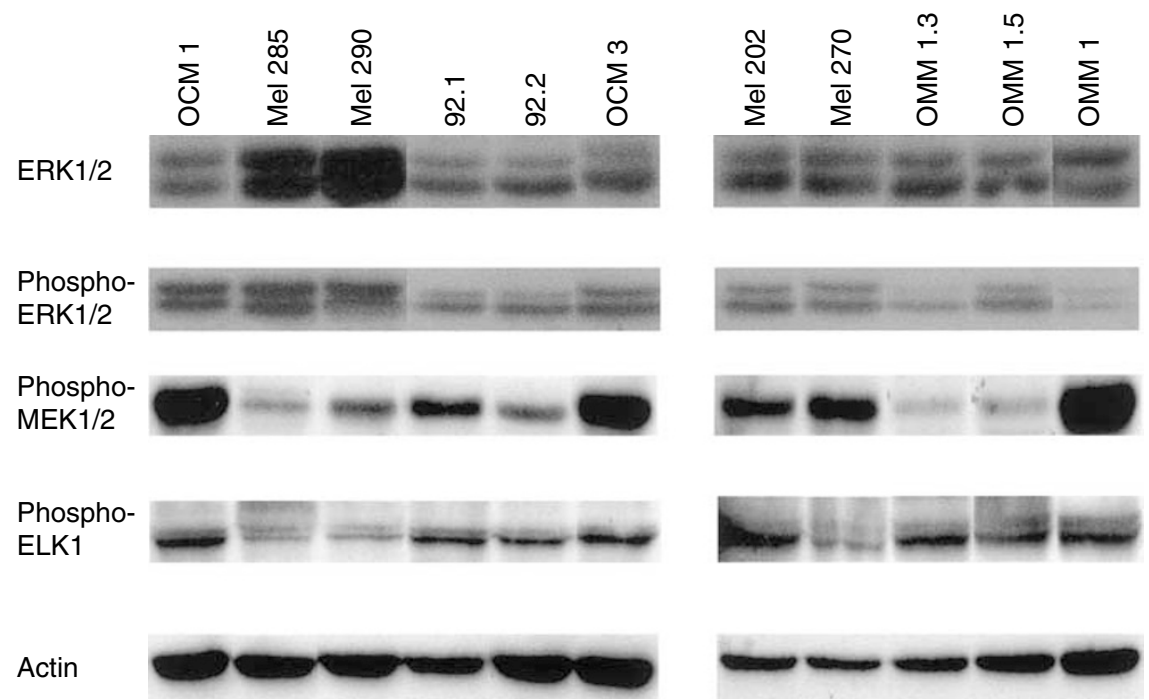

Figure I Expression levels of members of the MAPK pathway downstream of RAS and BRAF in I I uveal melanoma cell lines. Actin levels were assessed as a loading control.

Table 3 Summary of published RAS and BRAF mutation studies in ocular melanoma

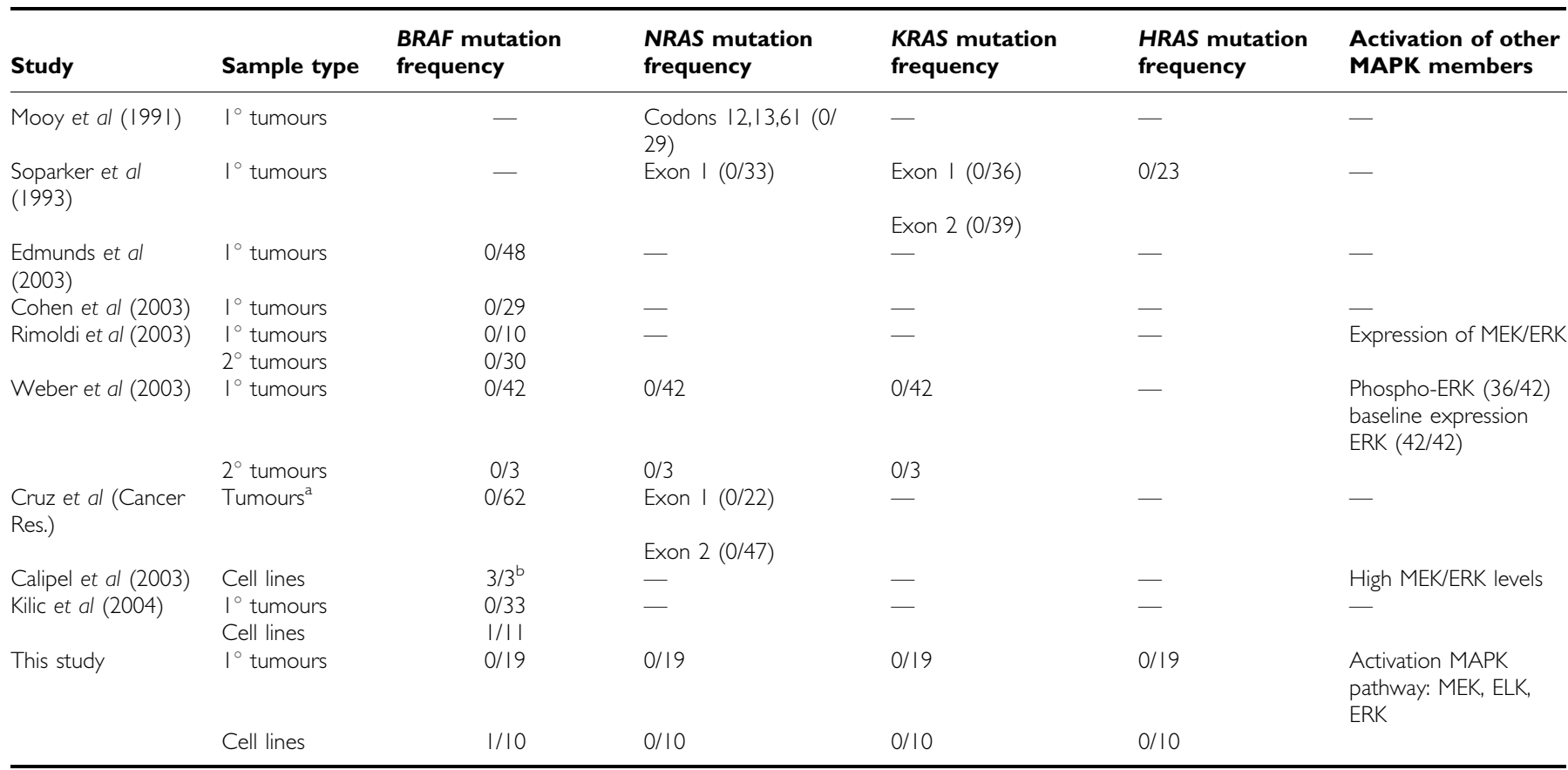

${ }^{a}$ Not specified if samples were from primary or secondary tumours. ${ }^{b}$ All V599E.

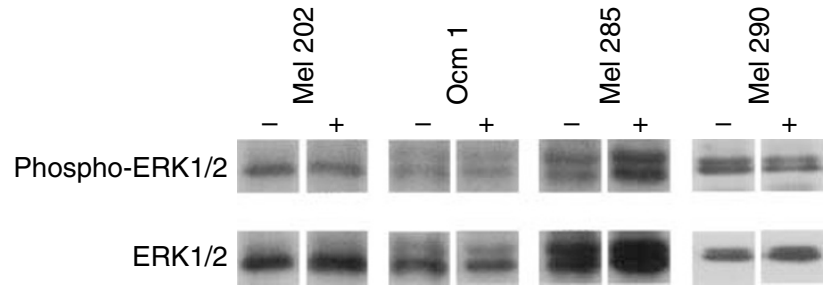

Figure 2 ERKI/2 and phospho-ERKI/2 expression in uveal melanoma cell lines (Mel 202, Ocm I, Mel 285, Mel 290) cultured with $(+)$ and without ( - ) serum $(24 \mathrm{~h})$. A similar lack of effect of serum on influencing the level of phospho-ERKI/2 was seen for each of the other uveal melanoma cell lines (data not shown). activation in uveal melanoma, independent of $R A S$ and $B R A F$ mutations, has also been reported recently by others (Rimoldi et al, 2003; Weber et al, 2003; ), but the mechanism is unknown. Recently, an interaction has been found between the MAPK and the PTEN pathways, both frequently activated in parallel to promote cutaneous melanoma development (Tsao et al, 2004). It is tempting to speculate that MAPK activation in uveal melanoma may arise via crosstalk with the PI3K/PTEN/AKT pathway, possibly as a consequence of mutation of some of its components (other than PTEN, which is not mutated in this tumour type). Thus, mutation analysis of the PI3K and AKT gene families in uveal melanomas seems warranted. Interestingly, Graells et al (2004) demonstrated that the proangiogenic vascular endothelial growth factor (VEGF), which is frequently highly expressed in 
uveal melanoma (Stitt et al, 1998; Sheidow et al, 2000), could operate in cutaneous melanoma as a survival factor through increasing MAPK and PI3K pathway activity. It is possible that MAPK activation is such a crucial requirement for uveal melanoma development because it similarly provides survival, and/or antiapoptotic signals, necessary for tumour cell growth and maintenance.

Although many uveal melanoma samples have been studied for $B R A F$ and NRAS mutations, few have been analysed for MAPK activation and there is the implicit assumption that this pathway is not involved in uveal melanoma genesis. Our study is the only study design providing mutation information on all RAS members and expression data on a wide range of participants in the MAPK pathway. Our data thus support the notion that activation of MAPK is indeed involved in the development of uveal melanoma, but occurs via a different mechanism(s) to that in the majority of cutaneous melanomas. This conclusion has significant ramifications for the development of rational therapies to treat uveal melanoma as it implies that general inhibitors of the pathway may

\section{REFERENCES}

Alsina J, Gorsk DH, Germino FJ, Shih W, Lu SE, Zhang ZG, Yang JM, Hait WN, Goydos JS (2003) Detection of mutations in the mitogen-activated protein kinase pathway in human melanoma. Clin Cancer Res 9: 6419-6425 Brose MS, Volpe P, Feldman M, Kumar M, Rishi I, Gerrero R, Einhorn E, Herlyn M, Minna J, Nicholson A, Roth JA, Albelda SM, Davies H, Cox C, Brignell G, Stephens P, Futreal PA, Wooster R, Stratton MR, Weber BL (2002) BRAF and RAS mutations in human lung cancer and melanoma. Cancer Res 62: 6997-7000

Calipel A, Lefevre G, Pouponnot C, Mouriaux F, Eychene A, Mascarelli F (2003) Mutation of B-Raf in human choroidal melanoma cells mediates cell proliferation and transformation through the MEK/ERK pathway. $J$ Biol Chem 278: 42409-42418, doi:10.1074/jbcM308709200

Cohen Y, Goldenberg-Cohen N, Parrella P, Chowers I, Merbs SL, Pe'er J, Sidransky D (2003) Lack of BRAF mutation in primary uveal melanoma. Invest Ophthalmol Vis Sci 44: 2876-2878, doi:10.1167/iovs.02-1329

Cohen Y, Rosenbaum E, Begum S, Goldenberg D, Esche C, Lavie O, Sidransky D, Westra WH (2004) Exon 15 BRAF mutations are uncommon in melanomas arising in nonsun-exposed sites. Clin Cancer Res 10: $3444-3447$

Cohen C, Zavala-Pompa A, Sequeira JH, Shoji M, Sexton DG, Cotsonis G, Cerimele F, Govindarajan B, Macaron N, Arbister JL (2002) Mitogenactivated protein kinase activation is an early event in melanoma progression. Clin Cancer Res 8: $3728-3733$

Cruz III F, Rubin BP, Wilson D, Town A, Schroeder A, Haley A, Bainbridge T, Heinrich MC, Corless CL (2003) Absence of BRAF and NRAS mutations in uveal melanoma. Cancer Res 63(18): 5761-5766

Davies H, Bignell GR, Cox C, Stephens P, Edkins S, Clegg S, Teague J, Woffendin H, Garnett MJ, Bottomley W, Davis N, Dicks E, Ewing R, Floyd Y, Gray K, Hall S, Hawes R, Hughes J, Kosmidou V, Menzies A, Mould C, Parker A, Stevens C, Watt S, Hooper S, Wilson R, Jayatilake H, Gusterson BA, Cooper C, Shipley J, Hargrave D, Pritchard-Jones K, Maitland N, Chenevix-Trench G, Riggins GJ, Bigner DD, Palmieri G, Cossu A, Flanagan A, Nicholson A, Ho JW, Leung SY, Yuen ST, Weber BL, Seigler HF, Darrow TL, Paterson H, Marais R, Marshall CJ, Wooster R, Stratton MR, Futreal PA (2002) Mutations of the BRAF gene in human cancer. Nature 417: 949 - 954, doi:10.1038/nature00766

de Waard-Siebinga I, Blom DJ, Griffioen M, Schrier PI, Hoogendoorn E, Beverstock G, Danen EH, Jager MJ (1995) Establishment and characterization of an uveal-melanoma cell line. Int J Cancer 62: 155-161

Diener-West M, Hawkins BS, Markowitz JA, Schachat AP (1992) A review of mortality from choroidal melanoma. II. A meta-analysis of 5-year mortality rates following enucleation, 1966 through 1988. Arch Ophthalmol 110: $245-250$

Dong J, Phelps RG, Qiao R, Yao S, Benard O, Ronai Z, Aaronson SA (2003) BRAF oncogenic mutations correlate with progression rather than initiation of human melanoma. Cancer Res 63(14): 3883-3885

Edmunds SC, Cree IA, Di Nicolantonio F, Hungerford JL, Hurren JS, Kelsell DP (2003) Absence of BRAF gene mutations in uveal melanomas in still be effective even though the tumours do not have mutations of RAS or BRAF.

\section{ACKNOWLEDGEMENTS}

We thank Dr AD Singh for generously providing a panel of fresh frozen primary uveal melanoma specimens, Dr M Bernsen and $\mathrm{P}$ Rombout for the cutaneaous melanoma sections (Department of Pathology, University Medical Centre Nijmegen) and Drs Ksander and Kan-Mitchell for providing some of the cell lines. This work was supported by the National Health and Medical Research Council of Australia, the 'Rotterdamse Vereniging Blindenbelangen' and the 'Landelijke Stichting voor Blinden en Slechtzienden'. FvN is supported by the Netherlands Organisation for Scientific Research and by the Dutch Cancer Society. NG is a recipient of an Aspasia fellowship of the Netherlands Organisation for Scientific Research. contrast to cutaneous melanomas. Br J Cancer 88: 1403-1405, doi:10.1038/sj.bjc.6600919

Gorden A, Osman I, Gai W, He D, Huang W, Davidson A, Houghton AN, Busam K, Polsky D (2003) Analysis of BRAF and N-RAS mutations in metastatic melanoma tissues. Cancer Res 63(14): 3955-3957

Graells J, Vinyals A, Figueras A, Llorens A, Moreno A, Marcoval J, Gonzalez FJ, Fabra A (2004) Overproduction of VEGF concomitantly expressed with its receptors promotes growth and survival of melanoma cells through MAPK and PI3K signaling. J Invest Dermatol 123: $1151-1161$

Guldberg P, thor Straten P, Birck A, Ahrenkiel V, Kirkin AF, Zeuthen J (1997) Disruption of the MMAC1/PTEN gene by deletion or mutation is a frequent event in malignant melanoma. Cancer Res 57: 3660-3663

Kan-Mitchell J, Mitchell MS, Rao N, Liggett PE (1989) Characterization of uveal melanoma cell lines that grow as xenografts in rabbit eyes. Invest Ophthalmol Vis Sci 30: 829-834

Kilic E, Bruggenwirth HT, Verbiest MM, Zwarthoff EC, Mooy NM, Luyten GP, De Klein A (2004) The RAS-BRAF kinase pathway is not involved in uveal melanoma. Melanoma Res 14: 203-205

Kumar R, Angelini S, Czene K, Sauroja I, Hahka-Kemppinen M, Pyrhonen S, Hemminki K (2003a) BRAF mutations in metastatic melanoma: a possible association with clinical outcome. Clin Cancer Res 9: 3362-3368

Kumar R, Angelini S, Hemminki K (2003b) Activating BRAF and N-Ras mutations in sporadic primary melanomas: an inverse association with allelic loss on chromosome 9. Oncogene 22: 9217-9224, doi:10.1038/ sj.onc.1206909

Luyten GP, Naus NC, Mooy CM, Hagemeijer A, Kan-Mitchell J, van Drunen E, Vuzevski V, de Jong PT, Luider TM (1996) Establishment and characterization of primary and metastatic uveal melanoma cell lines. Int J Cancer 66: 380 -387, doi:10.1002/(sici)1097-0215

Maldonado JL, Fridlyand J, Patel H, Jain AN, Busam K, Kageshita T, Ono T, Albertson DG, Pinkel D, Bastian BC (2003) Determinants of BRAF mutations in primary melanomas. J Natl Cancer Inst 95: 1878-1890

Miller SA, Dykes DD, Polesky HF (1988) A simple salting out procedure for extracting DNA from human nucleated cells. Nucl Acids Res 16: 1215

Mooy CM, de Jong PT (1996) Prognostic parameters in uveal melanoma: a review. Surv Ophthalmol 41: $215-228$

Mooy CM, Van der Helm MJ, Van der Kwast TH, De Jong PT, Ruiter DJ, Zwarthoff EC (1991) No N-ras mutations in human uveal melanoma: the role of ultraviolet light revisited. Br J Cancer 64: 411-413

Naus NC, Zuidervaart W, Rayman N, Slater R, van Drunen E, Ksander B, Luyten GP, Klein A (2000) Mutation analysis of the PTEN gene in uveal melanoma cell lines. Int J Cancer 87: 151-153

Omholt K, Platz A, Kanter L, Ringborg U, Hansson J (2003) NRAS and BRAF mutations arise early during melanoma pathogenesis and are preserved throughout tumor progression. Clin Cancer Res 9: 6483-6488 Pollock PM, Harper UL, Hansen KS, Yudt LM, Stark M, Robbins CM, Moses TY, Hostetter G, Wagner U, Kakareka J, Salem G, Pohida T, Heenan P, Duray 
P, Kallioniemi O, Hayward NK, Trent JM, Meltzer PS (2003) High frequency of BRAF mutations in nevi. Nat Genet 33: 19-20, doi:10.1038/ng1054

Reifenberger J, Knobbe CB, Sterzinger AA, Blaschke B, Schulte KW, Ruzicka T, Reifenberger G (2004) Frequent alterations of Ras signaling pathway genes in sporadic malignant melanomas. Int J Cancer 109: 377 -384, doi:10.1002/ijc. 11722

Rimoldi D, Salvi S, Lienard D, Lejeune FJ, Speiser D, Zografos L, Cerottini JC (2003) Lack of BRAF mutations in uveal melanoma. Cancer Res 63: $5712-5715$

Satyamoorthy K, Li G, Gerrero MR, Brose MS, Volpe P, Weber BL, Van Belle P, Elder DE, Herlyn M (2003) Constitutive mitogen-activated protein kinase activation in melanoma is mediated by both BRAF mutations and autocrine growth factor stimulation. Cancer Res 63: 756-759

Scott RJ, Vajdic CM, Armstrong BK, Ainsworth CJ, Meldrum CJ, Aitken JF, Kricker A (2002) BRCA2 mutations in a population-based series of patients with ocular melanoma. Int J Cancer 102: 188 -191, doi:10.1002/ijc.10693

Sheidow TG, Hooper PL, Crukley C, Young J, Heathcote JG (2000) Expression of vascular endothelial growth factor in uveal melanoma and its correlation with metastasis. Br J Ophthalmol 84: 750 - 756

Shinozaki M, Fujimoto A, Morton DL, Hoon DS (2004) Incidence of BRAF oncogene mutation and clinical relevance for primary cutaneous melanomas. Clin Cancer Res 10: 1753-1757

Sisley K, Rennie IG, Parsons MA, Jacques R, Hammond DW, Bell SM, Potter AM, Rees RC (1997) Abnormalities of chromosomes 3 and 8 in posterior uveal melanoma correlate with prognosis. Genes Chromosomes Cancer 19: 22-28, doi:10.1002/(sici)1098-2264(199705)

Soparker CN, O'Brien JM, Albert DM (1993) Investigation of the role of the ras protooncogene point mutation in human uveal melanomas. Invest Ophthalmol Vis Sci 34: 2203-2209
Stahl JM, Cheung M, Sharma A, Trivedi NR, Shanmugam S, Robertson GP (2003) Loss of PTEN promotes tumor development in malignant melanoma. Cancer Res 63: $2881-2890$

Stitt AW, Simpson DA, Boocock C, Gardiner TA, Murphy GM, Archer DB (1998) Expression of vascular endothelial growth factor (VEGF) and its receptors is regulated in eyes with intra-ocular tumours. J Pathol 186: $306-312$

Tsao H, Goel V, Wu H, Yang G, Haluska FG (2004) Genetic interaction between NRAS and BRAF mutations and PTEN/MMAC1 inactivation in melanoma. J Invest Dermatol 122: 337 - 341

Uribe P, Wistuba II, Gonzalez S (2003) BRAF mutation: a frequent event in benign, atypical, and malignant melanocytic lesions of the skin. Am J Dermatopathol 25: 365-370

van der Velden PA, Metzelaar-Blok JA, Bergman W, Hurks HMH, Frants RR, Gruis NA, Jager MJ (2001) Promoter hypermethylation: a common cause of reduced p16(INK4a) expression in uveal melanoma. Cancer Res 61: $5303-5306$

van Elsas A, Zerp SF, van der Flier S, Kruse KM, Aarnoudse C, Hayward NK, Ruiter DJ, Schrier PI (1996) Relevance of ultraviolet-induced N-ras oncogene point mutations in development of primary human cutaneous melanoma. Am J Pathol 149: 883-893

Weber A, Hengge UR, Urbanik D, Markwart A, Mirmohammadsaegh, Reichel MB, Wittekind C, Wiedemann P, Tannapfel A (2003) Absence of mutations of the BRAF gene and constitutive activation of extracellulrregulated kinase in malignant melanomas of the uvea. Lab Invest 83: 1771 - 1776, doi:10.1097/01.LAB.0000101732.89463.29

Yazdi AS, Palmedo G, Flaig MJ, Kutzner H, Sander CA (2003) SP-11 different frequencies of a BRAF point mutation in melanocytic skin lesions. Pigment Cell Res 16: 580 